\title{
LITERASI KIMIA MAHASISWA PGSD DAN GURU IPA SEKOLAH DASAR PADA TEMA UDARA
}

\author{
Atep Sujana \\ Prodi PGSD Universitas Pendidikan Indonesia \\ Jl. Mayor Abdurachman No. 211 Sumedang 45322 \\ Email: atepsujana261272@gmail.com
}

\begin{abstract}
This study aims to determine the chemical literacy of primary school teachers and students on the theme PGSD air. The method used is descriptive method, the research subjects totaling 61 people, 41 people came from PGSD students and 20 people from elementary school teachers. The instrument used is a matter of chemistry literacy tests are 40 multiple -choice questions that include reason or other information to strengthen the answers given, questionnaires, and interviews. Data processing techniques performed included determination of the limits of chemical literacy achievement, scoring each question, changing the score values, grouping study subjects based on the values obtained, and the analysis and conclusions. From the research data showed that only 26 people (63.41\%) students who have achieved literacy PGSD chemistry, whereas only 10 elementary school teachers (50\%) who had reached chemical literacy. Literacy chemical that has not reached most of the research subject primarily determine the chemical formula of constituent gases of air and to write the equation. Keywords: PGSD students, elementary science teachers, science literacy, literacy chemistry, descriptive method.
\end{abstract}

ABSTRAK

Penelitian ini bertujuan untuk mengetahui literasi kimia guru SD dan mahasiswa PGSD pada tema udara. Metode yang digunakan adalah metode deskriptif, dengan subyek penelitian berjumlah 61 orang, 41 orang berasal dari mahasiswa PGSD serta 20 orang dari guru SD. Instrumen yang digunakan berupa soal tes literasi kimia berjumlah 40 soal berbentuk pilihan berganda yang dilengkapi alasan atau keterangan lainnya untuk memperkuat jawaban yang diberikan, angket, serta wawancara. Teknik pengolahan data yang dilakukan meliputi penentuan batas ketercapaian literasi kimia, pemberian skor setiap soal, pengubahan skor menjadi nilai, pengelompokkan subyek penelitian berdasarkan nilai yang diperoleh, serta analisis dan kesimpulan. Dari hasil penelitian diperoleh data bahwa hanya 26 orang (63,41\%) mahasiswa PGSD yang telah mencapai literasi kimia, sedangkan guru SD hanya 10 orang (50\%) yang sudah mencapai literasi kimia. Literasi kimia yang belum tercapai kebanyakan subyek penelitian terutama menentukan rumus kimia gas penyusun udara serta menuliskan persamaan reaksi.

Kata Kunci: mahasiswa PGSD, guru IPA SD, literasi sains, literasi kimia, metode deskriptif.

PENDAHULUAN Ilmu pengetahuan dan teknologi (IPTEK) yang terjadi pada zaman sekarang berkembang sangat pesat, seingga berimbas pada semua aspek dalam kehidupan, termasuk pada bidang pendidikan. Seiring dengan perkembangan IPTEK tersebut, jumlah penduduk juga semakin hari semakin meningkat. Pertumbuhan jumlah penduduk yang semakin pesat dilain pihak berpengaruh positif terhadap peningkatan sumber daya manusia (SDM), namun di pihak lain berdampak pada berurangnya sumber daya alam (SDA). Lahan-lahan yang selama ini digunakan untuk pertanian, perikanan, perkebunan dan sebagainya, banyak digunakan untuk perumahan, perkantoran, sekolah, rumah sakit, jalan raya, industry, dan sebagainya. Pembangunan yang dilakukan manusia secara besar-besaran ini membawa dampak negative terhadap lingkungan hidup, sehingga menimbulkan pencemaran lingkungan (Sastrawijaya, 2009: 1). 
Pencemaran lingkungan merupakan suatu keadaan di mana kondisi lingkungan yang ada membahayakan bagi kesehatan manusia. Terjadinya pecemaran lingkungan ada yang terlihat oleh mata seperti terjadinya penumpukan sampah, ada yang terhirup oleh hidung seperti bau sampah atau bangkai yang membusuk, terdengar oleh telinga seperti kebisingan akibat kendaraan bermotor, bahkan ada pula yang tidak terdeteksi oleh panca indra manusia seperti gas-gas berbahaya yang dilepaskan dari cerobong asap pabrik mapun kendaraan bermotor. Dengan demikian, pencemaran lingkungan dapat terjadi pada air (pencemaran air) pada udara (pencemaran udara) serta pada tanah (pencemaran tanah). Tanah, air, dan udara yang sudah tercemar tidak dapat digunakan oleh manusia, karena dapat menimbulkan berbagai macam penyakit.

Udara merupakan campuran berbagai macam gas. Udara yang digunakan manusia harus merupakan udara yang bersih, bebas dari bahanbahan yang menggangu atau bahan-bahan pencemar udara. Apabila udara yang ada telah tercemar, maka udara tersebut tidak baik digunakan untuk kehidupan manusia. Berbagai aktivitas manusia, terutama yang menggunakan peralatan modern seperti pendingin ruangan $(\mathrm{AC})$, lemari es, kendaraan bermotor, proses memasak, dan sebagainya dapat menghasilkan bahan-bahan pencemar udara. Bahan-bahan tersebut dapat meningkatkan konsentrasi gas karbon dioksida $\left(\mathrm{CO}_{2}\right)$, nitrogen dioksida $\left(\mathrm{NO}_{2}\right)$, metana $\left(\mathrm{CH}_{4}\right)$, serta partikulat-partikulat lainnya yang semuanya dapat mencemari udara. Pencemaran udara juga dapat terjadi karena peristiwa alam seperti kebakaran hutan dan gunung berapi. Apabila udara yang ada di sekitar telah tercemar, maka dapat menimbulkan berbagai dampak negative bagi manusia, mulai dari yang paling ringan seperti pusing, sampai pada kematian.

Mengingat pencemaran lingkungan berbahaya bagi kesehatan manusia, maka manusia harus senantiasa berusaha agar pencemaran tersebut tidak terjadi, serta melakukan pemecahan masalah agar pencemaran yang sudah terjadi dapat diatasi. Salah satu upaya untuk mengatasi pencemaran lingkungan serta menyiapkan diri dalam menghadapi kemajuan IPTEK adalah melalui pendidikan. Pendidikan dapat berlangsung secara formal, informal, maupun non formal. Pendidikan formal merupakan pendidikan yang berjenjang, mulai dari pendidikan pra sekolah, pendidikan dasar, pendidikan menengah, sampai pendidikan tinggi. Salah satu pendidikan tinggi yang berusaha mendidik para mahasiswanya untuk menjadi calon guru sekolah dasar (SD) adalah pendidikan guru sekolah dasar (PGSD). Salah satu mata kuliah yang diberikan pada mahasiswa PGSD adalah mata kuliah yang berhubungan dengan ke-IPAan.

Ilmu pengetahuan alam (IPA) atau disebut pula sains merupakan salah satu ilmu pengetahuan yang mempunyai peran penting dalam kehidupan manusia, sehingga diberikan mulai siswa sekolah dasar (SD) sampai perguruan tinggi (PT). IPA mempelajari alam semesta dan segala isinya beserta berbagai perubahan yang terjadi di alam tersebut. IPA juga dikatakan sebagai salah satu pendekatan yang sistematis dalam mempelajari alam semesta. IPA mengajukan berbagai pertanyaan yang mendasar mengenai alam semesta, seperti bagaimana alam semesta terbentuk, bagaimana keadaan alam semesta sekarang, serta apa yang akan terjadi dengan alam semesta ini di masa yang akan datang.

Pertanyaan-pertanyaan tersebut tentu hanya dapat dijawab melalui kegiatan ilmiah yang dilakukan para ahli, mulai dari observasi, pengumpulan data, analisis data, pengajuan hipotesis, pengujian hipotesis, interpretasi dan akhirnya diperoleh kesimpulan. Hal tersebut sesuai dengan yang dikemukakan Spellings (2006:4), bahwa sains bukan hanya berupa kumpulan tentang fakta-fakta saja, tetapi lebih jauh dari itu sains melibatkan beberapa aspek seperti mengamati apa yang terjadi, melakukan pengklasifikasian, memprediksi kemungkinan apa yang akan terjadi, melakukan pengujian, serta menarik kesimpulan dari hasil pengujian yang telah dilakukan. Hal senada juga dikemukakan Glenn (2010: 1) bahwa sains merupakan salah satu studi yang berusaha untuk memahami sesuatu yang ada di alam berdasarkan data empiris. Ide-ide pokok yang terdapat dalam sains sesuai dengan fakta-fakta yang tidak bias dan dapat diverifikasi. 
Meskipun sains dapat menjawab berbagai permasalahan yang terjadi, namun tidak semua permasalahan dapat terjawab dengan sains. Masalah moral, nilai, dan keyakinan dalam beragama, tidak dapat dijawab oleh sains. Namun demikian, sains dapat memberikan bukti-bukti yang dapat membantu seseorang dalam membuat keputusan, memberikan pertimbangan mengenai nilai positif dan negatif yang terjadi pada diri seseorang atau kelompok orang dalam mengambil keputusan (Merwa, 2005:5).

Sains menurut Trefil (2010: 1) terdiri dari beberapa cabang, yaitu biologi, fisika, kimia, lingkungan, geologi, kesehatan dan keselamatan, astronomi, serta tekhnologi. Dengan demikian, ilmu kimia merupakan bagian dari sains. Ilmu kimia merupakan ilmu pengetahuan yang mempelajari bahan-bahan kimia, termasuk semua materi yang ada di alam sekitar, baik yang berupa bahan alami maupun bahan buatan. Ilmu kimia juga berusaha untuk menemukan komponen-komponen apa saja yang menyusun suatu zat, sehingga memungkinkan seseorang dapat membuat bahan baru dengan sifat yang baru dan lebih berguna. Di samping itu, ilmu kimia juga berusaha untuk memberikan pemahaman lebih baik dari beberapa hal yang mendasari bekerjanya alam semesta (Brady, 1993). Ilmu kimia memusatkan kajiannya pada materi, sifat-sifat materi, struktur materi, komposisi materi, ikatan yang terjadi pada materi, perubahan materi, serta energy yang terlibat dalam perubahan materi tersebut. Hal ini sejalan dengan yang dikemukakan oleh Paul Kelter, at all. (2009:4), bahwa ilmu kimia berkaitan dengan studi yang melibatkan komposisi, struktur, sifat materi, perubahan materi, serta energy yang terlibat pada perubahan materi tersebut. Secara informal, istilah ilmu kimia atau bahan kimia sering hanya terbatas pada bahan-bahan yang dihasilkan oleh industry kimia, obat-obatan, bom, serta racun. Sebenarnya bahan-bahan kimia yang dibutuhkan oleh manusia lebih luas dari itu.

Ilmu kimia sangat penting dalam kehidupan manusia, karena kehidupan manusia pada zaman modern seperti sekarang sangat bergantung pada bahan-bahan kimia. Dengan mempelajari ilmu kimia, maka hidup seseorang akan lebih mudah dan lebih baik. Hal tersebut sesuai dengan yang dikemukakan Glen (2010: 4) bahwa mempelajari ilmu kimia merupakan suatu motivasi yang kuat dalam mengembangkan tehnologi yang dapat membuat hidup seseorang menjadi lebih baik. Beberpa bahan kimia yang erat kaitannya dengan kehidupan manusia dan sangat membantu dalam menyelesaikan masalah dalam kehidupan seperti perangkat komputer, televisi, makanan, minuman, obat-obatan, pemutih, pembersih, pengharum ruangan, kendaraan, tanah, udara, peralatan rumah tangga, dan sebagainya.

Mengingat pentingnya ilmu kimia bagi kehidupan, maka sangat penting bagi para siswa untuk memahami mengenai ilmu kimia sejak dini. Meskipun ilmu kimia tidak secara khusus diajarkan pada siswa sekolah dasar (SD), namun banyak konsep-konsep dasar kimia yang harus dikuasai oleh siswa SD yang terdapat pada air, udara, tanah, makanan, obat-obatan, dan sebagainya. Pada tema udara misalnya, banyak konsep dasar kimia yang harus dikuasai para siswa seperti pada proses potosintesis, dimana gas karbon dioksida $\left(\mathrm{CO}_{2}\right)$ bereaksi dengan air $\left(\mathrm{H}_{2} \mathrm{O}\right)$ untuk membentuk karbohidrat $\left(\mathrm{C}_{6} \mathrm{H}_{12} \mathrm{O}_{6}\right.$ serta gas oksigen $\left(\mathrm{O}_{2}\right)$. Proses ini merupakan proses penting bagi kehidupan manusia dan juga bagi mahluk hidup lainnya, karena dari proses ini dilepaskan gas oksigen yang dibutuhkan untuk melakukan proses pernapasan, pembakaran, serta proses lainnya. Secara sederhana, persamaan rekasi potosintesis dapat dituliskan:

$$
6 \mathrm{H}_{2} \mathrm{O}(\mathrm{g})+6 \mathrm{CO}_{2}(\mathrm{~g}) \rightarrow \mathrm{C}_{6} \mathrm{H}_{12} \mathrm{O}_{6}(\mathrm{~s})+6 \mathrm{O}_{2}(\mathrm{~g})
$$

Agar para siswa SD mempunyai kemampuan yang lebih baik dalam mempelajarai IPA, terutama yang berhubungan dengan konsepkonsep dasar kimia, maka guru yang mengajar IPA di SD harus mempunyai pengetahuan IPA yang memadai, terutama mengenai konsepkonsep dasar kimia. Hal ini karena dalam proses pembelajaran di SD guru paling sering berinteraksi dengan para siswa, sehingga peranan guru sangat menentukan hasil belajar para siswa. Guru juga bukan hanya berkewajiban menanamkan konsep dan proses dalam pembelajaran, tetapi juga menanamkan sikap kepada para siswanya yang tidak dapat diberikan oleh media apapun. Peranan guru yang sangat vital menjadikan guru sebagai salah satu komponen terpenting dalam menentukan 
keberhasilan pembelajaran tersebut. Sagala (2008: 6) mengemukakan bahwa "guru bertugas merencanakan dan melaksanakan proses pembelajaran, menilai hasil pembelajaran, melakukan bimbingan dan latihan, melakukan penelitian dan pengkajian, serta membuka komunikasi dengan masyarakat".

Mengingat peran guru dalam pembelajaran yang sangat penting, maka seorang guru harus mempunyai kemampuan yang lebih dibandingkan yang lainnya, dalam meningkatkan mutu pendidikan. Pembelajaran yang dilakukan oleh guru juga harus dapat membangkitkan minat siswa untuk belajar, sehingga pembelajaran menjadi lebih bermakna. Bukan hanya guru, calon guru SD (mahasiswa PGSD) juga harus memiliki kemampuan yang lebih baik agar nanti pada saatnya melaksanakan tugas sebagai guru dapat melaksanakan pembelajaran dengan sebaik-baiknya. Oleh karena itu, sangat penting bagi para guru IPA di SD serta mahasiswa PGSD untuk memiliki pengetahuan yang mendalam mengenai ilmu kimia. Dengan kata lain, guru SD dan mahasiswa PGSD harus mempunyai literasi kimia yang baik.

Literasi menurut PISA (Programe for International Student Assesment; 2006 dianggap sebagai pengetahuan dan keterampilan untuk kehidupan manusia. Literasi diperoleh melalui proses sepanjang hayat, berlangsung tidak hanya di sekolah atau melalui pendidikan formal, tetapi juga melalui interaksi dengan teman-teman dan masyarakat secara luas. Pemahaman terhadap literasi dalam PISA mempunyai potensi yang besar untuk dijadikan sebagai wahana mengembangkan berbagai kemampuan berpikir tingkat tinggi, kemampuan bekerja keras, berbagai keterampilan dasar, bersikap jujur, berdisiplin dan sebagainya. PISA juga mendefinisikan literasi sains sebagai kemampuan seseorang dalam menggunakan pengetahuan sains untuk mengidentifikasi berbagai pertanyaan serta menarik kesimpulan berdasarkan bukti-bukti yang dapat membantu seseorang dalam mengambil keputusan mengenai dunia ilmiah dan serta hubungan antara manusia dengan alam

Ilmu kimia merupakan bagian dari sains, sehingga literasi kimia juga merupakan bagian dari literasi sains. Literasi kimia merupakan salah satu elemen penting yang harus dikembangkan dalam pendidikan. Literasi kimia berhubungan dengan semua manusia dari segala umur, semua jenjang pendidikan baik sains maupun non sains. Gilbert dan Treagust; 2009 (dalam Lin, 2009) mengklaim bahwa banyak aspek literasi kimia yang memiliki aplikasi langsung dalam kehidupan sehari-hari, sehingga memungkinkan seseorang menjadi warga negara yang lebih baik dan memungkinkan seseorang untuk memahami laporan dan mendiskusikan tentang ilmu kimia dan bahan-bahan kimia, serta dapat mengatasi berbagai isu lingkungan dalam kehidupan sehari-hari seperti efek rumah kaca, penipisan ozon, keasaman, dan sebagainya.

Literasi kimia menurut Shwartz, Ben-Zvi, \& Hofstein, 2005 (dalam Gilbert and Treagust, 2009), melibatkan beberapa komponen, seperti:

1. Memahami sifat kimia, norma-norma dan metode. Artinya, bagaimana ahli kimia bekerja dan bagaimana produk-produk yang dihasilkan diterima sebagai pengetahuan ilmiah;

2. Memahami teori, konsep dan model kimia. Subyek terletak pada teori yang memiliki aplikasi luas;

3. Memahami bagaimana ilmu kimia dan teknologi berbasis kimia berhubungan satu sama

lain. Ilmu kimia berusaha menghasilkan penjelasan tentang alam, sedangkan teknologi kimia berusaha untuk mengubah dunia itu sendiri. Konsep dan model yang dihasilkan oleh kedua bidang memiliki keterkaitan kuat, sehingga satu sama lain saling berpengaruh.

4. Menghargai dampak ilmu kimia dan teknologi kimia yang terkait dengan masyarakat. Memahami sifat dari fenomena kimia yang berlaku. Menghasilkan perubahan atau variasi pada fenomena yang lebih baik dengan cara mengubah dunia yang kita lihat.

Untuk mengetahui sejauh mana literasi kimia yang dimiliki guru SD dan mahasiswa PGSD, telah dilakukan penelitian terhadap beberapa guru SD dan juga mahasiswa PGSD pada tema udara. Ada beberapa alasan literasi kimia yang diteliti hanya pada tema udara, yaitu: (1) tema udara sangat luas dan memiliki aplikasi penting bagi kehidupan, sehingga untuk memahami secara utuh dibutuhkan pemilikiran yang serius. (2) Udara merupakan komponen dasar bagi kehidupan, sehingga apabila udara tidak ada, 
maka kehidupan juga tidak akan ada. (3) Udara sangat erat dengan kehidupan sehari-hari para siswa SD dan mahasiswa PGSD, baik di lingkungan sekolah, di rumah, maupun di lingkungan masyarakat. (4) Selain erat dengan kehidupan sehari-hari siswa, tema udara juga diberikan pada pelajaran IPA di SD, sehingga para guru SD dan mahasiswa PGSD harus mempunyai literasi yang tinggi untuk tema udara.

\section{METODE}

Metode yang digunakan dalam penelitian ini adalah metode deskriptif. Mukhtar (2013: 10) mengemukakan bahwa "metode deskriptif merupkan metode penelitian yang dimaksudkan untuk mengumpulkan informasi mengenai subyek penelitian dan perilaku subyek penelitian pada suatu periode tertentu". Dalam hal ini informasi yang dikumpulkan adalah mengenai literasi kimia guru SD serta mahasiswa PGSD pada tema air.

Subyek dalam penelitian ini adalah guru SD dan mahasiswa PGSD yang berjumlah 61 orang, di mana 20 orang berasal dari guru SD, serta 41 orang berasal dari mahasiswa PGSD. Guru SD yang digunakan sebagai subyek dalam penelitian ini adalah guru SD yang sedang melanjutkan kembali perkuliahannya pada jenjang S-1, namun mereka telah melaksanakan tugas sebagai pegawawi negri pada SD selama minimal 5 tahun.

Instrumen yang digunakan dalam penelitian ini terdiri dari tiga jenis, yaitu soal tes literasi kimia, wawancara, serta angket. Soal tes literasi kimia yang digunakan berjumlah 40 soal berbentuk pilihan berganda yang dilengkapi dengan alasan atau keterangan lainnya untuk memperkuat jawaban yang mereka berikan. Soal tes literasi kimia ini mencakup aspek konten, konteks, proses, serta sikap ilmiah. Dalam pelaksanaannya, kepada semua subyek penelitian diberikan satu set soal literasi kimia, untuk diselesaikan selama 120 menit. Tempat duduk mereka juga didesain sedemikian rupa dan dilakukan pengawasan yang ketat, sehingga satu sama lain tidak data bekerja sama.

Wawancara dan angket diberikan pada subjek penelitian untuk mengetahui hal-hal lain yang belum tergali oleh soal tes. Wawancara yang digunakan dalam penelitian ini merupakan wawancara terpimpin. Arikunto (2013: 44) mengemukakan bahwa "wawancara terpimpin dilakukan oleh subyek evaluasi dengan cara mengajukan pertanyaan-pertanyaan yang sudah tersusun". Wawancara dilakukan terhadap mahasiswa PGSD serta guru IPA SD. Angket atau kuesioner yang digunakan merupakan kuesioner langsung, dimana responden mejawab langsung kuesioner tersebut, dan dikumpulkan langsung setelah diisi oleh responden. Kuesioner ini antara lain digunakan untuk mengetahui latar belakang mahasiswa, motivasi mahasiswa dalam mengikuti perkuliahan konsep dasar kimia, minat mahasiswa, kebutuhan mahasiswa, kesesuaian antara materi yang diberikan dengan kebutuhan di

Teknik pengolahan data yang digunakan disesuaikan dengan data yang diperoleh, yang meliputi beberapa tahapan, yaitu:

1. Penentuan batas kriteria minimum untuk menentukan apakah guru SD serta mahasiswa PGSD tersebut sudah mencapai literasi kimia atau belum. Dalam penelitian ini, batas minimum untuk dikatakan sudah mencapai literasi kimia adalah 65. Jadi mahasiswa PGSD dan guru SD yang memperoleh nilai $\geq 65$ dinyatakan sudah mencapai lietrasi kimia, dan yang mendapat nilai $<65$ dinyatakan belum mencapai literasi kimia.

2. Pemberian skor untuk setiap soal, dimana skor maksimum untuk setiap soal adalah 2, sehingga skor maksimum adalah 80 .

3. Pengubahan skor yang diperoleh menjadi nilai, dengan menggunakan persamaan:

$$
\text { Nilai }=\frac{\text { skor yang diperoleh }}{\text { Skor maksimum }} \times 100
$$

4. Mengelompokan subyek penelitian berdasarkan nilai yang diperolehnya, ke dalam kelompok yang sudah mencapai literasi kimia dan yang belum mencapai literai kimia,.

5. Setelah dilakukan pengolahan data selanjutnya dilakukan analisis terhadap data tersebut untuk dilakukan analisis dan deskripsi lebih lanjut.

\section{HASIL DAN PEMBAHASAN}

Setelah dilakukan kegiatan pengumpulan data terhadap guru SD serta mahasiswa PGSD, maka tahap selanjutnya adalh mengolah data tersebut untuk disimpulkan. Dari hasil tes 
terhadap mahasiswa PGSD serta guru IPA SD diperoleh data sebagai berikut:

Tabel 1. Sebaran Nilai Literasi Kimia Mahasiswa PGSD dan Guru SD pada Tema Air

\begin{tabular}{|c|c|c|c|c|c|c|c|c|}
\hline \multirow{2}{*}{ No } & \multirow{2}{*}{ Subyek } & \multirow{2}{*}{ Jumlah } & \multirow{2}{*}{ Terendah } & \multirow{2}{*}{ Tertinggi } & \multirow{2}{*}{$\begin{array}{l}\text { Rata- } \\
\text { Rata }\end{array}$} & \multirow{2}{*}{$\begin{array}{c}\text { Simpangan } \\
\text { Baku }\end{array}$} & \multicolumn{2}{|c|}{ Ketercapaian } \\
\hline & & & & & & & Tercapai & Belum \\
\hline 1 & $\begin{array}{c}\text { Mahasiswa } \\
\text { PGSD }\end{array}$ & 41 & 60,00 & 85,00 & 68,60 & 7,13 & 26 & 15 \\
\hline 2 & Guru SD & 20 & 55 & 80 & 65,69 & 6,48 & 10 & 10 \\
\hline
\end{tabular}

Berdasarkan tabel di atas, terlihat bahwa masih bayak mahasiswa PGSD serta guru SD yang belum mencapai literasi kimia, padahal batas minimal untuk mencapai literasi kimia terbilang kecil, yaitu 65,00. Pada mahasiswa PGSD, dari 4 mahasiswa, ternyata baru 26 mahasiswa $(63,41 \%)$ yang sudah mencapai literasi kimia, serta sisanya 15 mahasiswa (36,59\%) belum mencapai literasi kimia. Hal yang lebih parah terjadi pada guru SD, di mana dari 20 guru tersebut yang sudah mencapai literasi kimia 10 orang $(50 \%)$ dan yang belum mencapai literasi kimia juga 10 orang (50\%). Kondisi ini menujukkan bahwa pembelajaran konsep dasar kimia harus lebih ditingkakan lagi untuk mencapai literasi kimia mahasiswa dan guru yang lebih tinggi.

Untuk lebih mempermudah dalam mempelajarinya, dari data tabel 1 , selanjutnya diubah ke dalam bentuk diagram berikut.

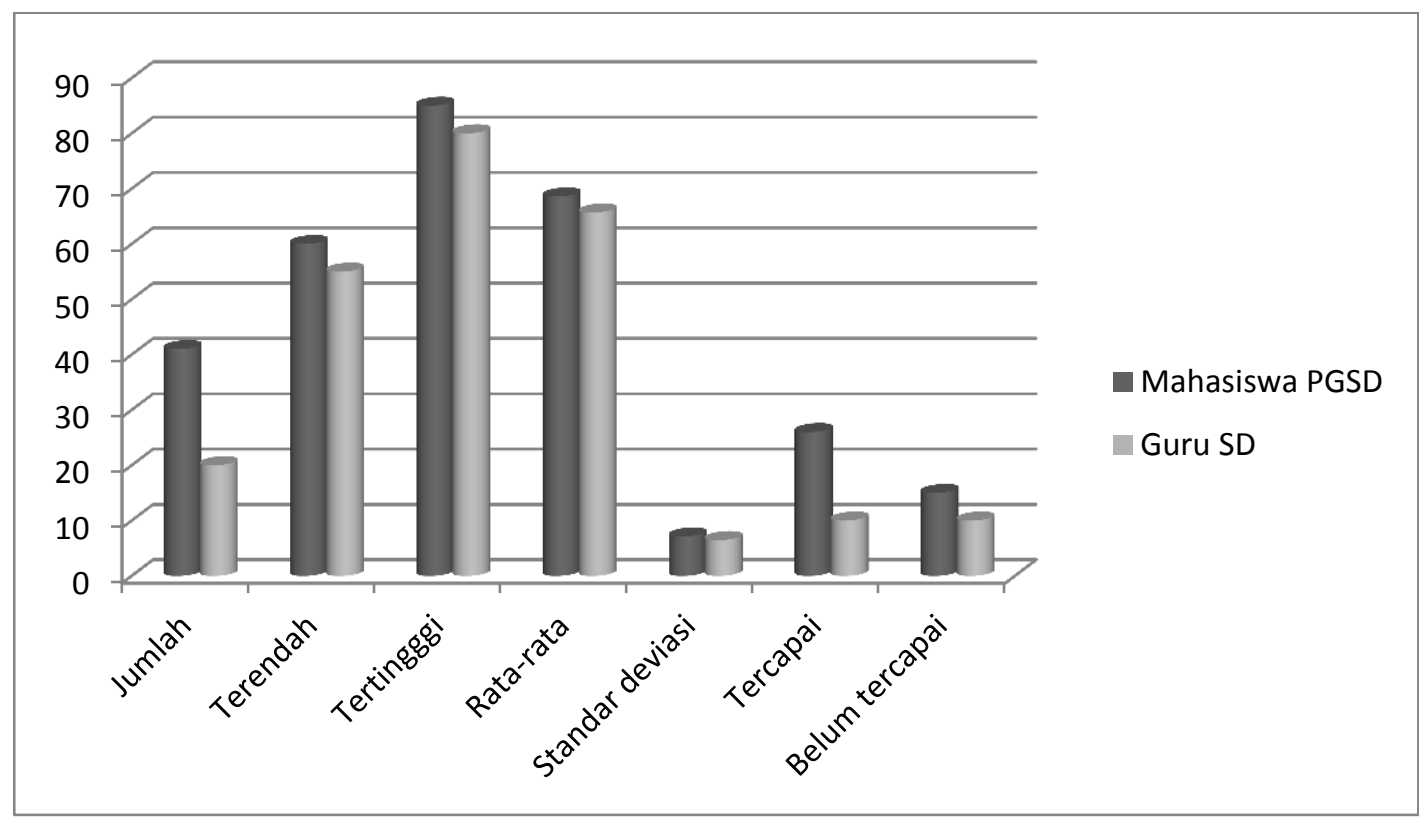

Diagram 1. Ketercapaian Literai Kimia Mahasiswa PGSD dan Guru SD

Rendahnya literasi kimia yang dimiliki mahasiswa PGSD dan guru SD, merupakan salah satu permasalahan yang harus segera diatasi, karena literasi kimia kimia sangat penting dalam kehidupan sehari-hari yang memiliki aplikasi langsung bagi kehidupan. Guru SD dan mahasiswa PGSD juga harus mempunyai kemampuan literasi kimia yang tinggi karena literasi kimia merupakan bagian dari literasi sains. Rendahnya literasi kimia guru SD dan mahasiswa PGSD sangat berpengaruh terhadap pembelajaran IPA di SD. Apabila literasi kimia guru dan mahasiswa PGSD rendah, maka dikhawatirkan pembelajaran IPA yang dilaksanakan di SD kurang baik.

Hal lain yang menyebabkan pentingnya literasi kimia dikuasai oleh para guru SD dan juga mahasiswa PGSD sebagai calon guru SD adalah karena literasi kimia berhubungan dengan berbagai aspek kehidupan dalam masyarakat, berhubungan dengan aktivitas seseorang dari segala usia baik tua maupun muda. Lin (2009) mengemukakan bahwa literasi kimia berhubungan dengan masyarakat dari segala usia, sehingga perlu ditingkakan untuk mencapai literasi kimia yang lebih tinggi. 
Para guru dan juga mahasiswa PGSD sebagai calon guru SD harus mempunyai literasi yang tinggi karena peranan guru sangat penting dalam melaksanakan pembelajaran. Peranan guru yang sangat vital menjadikan guru sebagai salah satu komponen penting yang menentukan keberhasilan para siswa. Oleh karena itu seorang guru harus mempunyai kemampuan yang tinggi dalam literasi kimia, serta pengetahuan lainnya. Saud (2010: 33) mengemukakan bahwa guru dituntut untk memiliki seperangkat pengetahuan dan keterampilan teknis mengajar disamping menguasai ilmu atau bahan yang akan diajarkannya. Keberhasilan siswa dalam pembelajaran sangat ditentukan oleh kemampuan guru dalam mengajar. Dilain pihak, guru juga perlu membimbing dan mengarahkan siswanya agar mereka mempunyai literasi sains yang tinggi. Hal tersebut sesuai yang dikemukakan Shwartz, Yael; Ben-Zvi, Ruth, and Hofstein, Avi (2005) bahwa sebagai guru harus mendukung pengembangan literasi kimia, untuk memberi kesempatan para siswa dalam membangun makna literasi sains.

Rendahnya literasi kimia mahasiswa PGSD dan guru SD menunjukkan masih banyaknya konteks, konten, proses, serta sikap ilmiah dalam konsep dasar kimia yang belum tercapai. Masih banyak diantara para guru dan mahasiswa PGSD yang belum memahami lebih mendalam mengenai konsep-konsep yang ada dalam ilmu kimia tertama pada tema udara, padahal konsepkonsep tersebut sangat penting dalam mengembangkan konsep-konsep yang ada pada pembelajaran IPA di sekolah dasar.

Dari hasil penelitian yang telah dilakukan diperoleh beberapa konteks, konten, serta proses yang mayoritas belum dicapai mahasiswa PGSD dan guru SD. Pada konteks kualitas udara adalah mahasiswa PGSD dan guru SD banyak yang belum dapat menentukan lambang unsur serta rumus kimia gas-gas penyusun udara, terutama lambing unsure dan rumu kimia senyawa yang di sekolah dasar tidak ada. Adapun untuk rumus kimia gas oksigen $\left(\mathrm{O}_{2}\right)$, gas karbon dioksida $\left(\mathrm{CO}_{2}\right)$ serta air $\left(\mathrm{H}_{2} \mathrm{O}\right)$, secara umum mahasiswa dan guru SD sudah dapat menuliskannya. Dalam menuliskan gas-gas penyusun udara, mereka banyak yang mengalami kesulitan mengubah dari nama senyawa ke rumus kimianya serta sebaliknya mengubah dari rumus kimia menjadi nama senyawanya.

Hal yang sama terjadi pada saat diminta untuk menuliskan persamaan reaksi kimia. Mereka banyak yang engalami kesulitan dalam menyetarakan persamaan reaksi, serta menentukan koefisien reaksi. Berdasarkan hasil wawancara diketahui bahwa kesulitan mereka (terutama para guru SD) dalam menuliskan persamaan reaksi, menyetarakan persamaan reaksi, serta menuliskan koefisien reaksi karena selama ini mereka tidak pernah menuliskan persamaan reaksi selama mengajar IPA di SD. Mereka lebh sering menuliskannya dalam bentuk kalimat, seperti pada proses potosintesis, mereka lebih mengetahui dengan kalimat "potosintesis merupakan proses pembentukan zat makanan atau zat gula yang terjadi pada tumbuhan".

Demikian pula konteks sifat-sifat udara, mereka masih banyak yang mengalami kesulitan dalam menentukan sifat-sifat gas penyusun udara. Banyak diantara mahasiswa PGSD dan guru SD yang belum dapat memberikan penjelasan mengenai sifat gas karbon dioksida $\left(\mathrm{CO}_{2}\right)$ dan sifat gas karbon monoksida (CO). mereka menganggap bahwa "kedua gas ini sama-sama beracun, karena berbahaya bagi kehidupan manusia". Padahal yang sebenarnya adalah gas karbon dioksida merupakan gas yang tidak beracun, bahkan dalam jumlah tertentu sangat dibutuhkan oleh tumbuhan untuk melakukan potosintesis. Berbeda dengan gas karbon dioksida, gas karbon monoksida merupakan gas beracun. Berdasarkan hasil wawancara terhadap para guru mereka mengalami kesulitan karena hal tersebut masih asing bagi mereka. Hal tersebut disebabkan karena kebanyakan para guru SD tidak berlatar pendidikan IPA, melainkan non IPA, bahkan kebanyakan berasal dari sekolah pendidikan guru (SPG), serta pada saat melaksanakan pembelajaran di kelas, mereka terfokus pada buku sumber (buku paket).

\section{SIMPULAN}

Berdasarkan uraian yang telah dikemukakan di atas, diketahui bahwa literasi kimia mahasiswa PGSD dan guru SD terutama pada tema udara belum sesuai dengan harapan. Masih banyak diantara mereka yang literasi kimianya masih rendah, meskipuan sudah tercapai. Ini 
dibuktikan dengan sedikitnya dari mereka yang telah mencapai literasi kimia, bahkan untuk guru $\mathrm{SD}$, ternyata literasi kimia mereka masih sangat rendah. Untuk mahasiswa PGSD, dari 41 mahasiswa yang dijadikan subyek penelitian, hanya 26 orang mahasiswa $(63,41 \%)$ yang sudah mencapai literasi. Kondisi ini juga lebih menghawatirkan lagi, karena dari ke 26 mahasiswa yang sudah mencapai literasi tersebut, nilainya masih rendah. Terbukti dari rata-rata nilai yang diperoleh mahasiswa PGSD hanya 68,60 . Hal yang lebih parah terjadi pada guru SD, dimana dari 20 guru yang dijadikan sebagai subyek penelitian, 10 orang (50 \%) diantaranya belum mencapai literasi kimia. Ini menunjukkan betapa masih lemahnya penguasaan konsep dasar kimia par guru, padahal untuk tema udara bukan merupakan hal yan aneh, karena udara banyak dimanfaatkan dalam kehidupan sehari-hari.

Disamping konteks, konten, serta proses mahasiswa dan guru yang masih rendah, kemampuan mereka dalam memecahkan maslaah juga masih kurang sesuai dengan harapan. Ini dibuktikan dari kesulitan mreka dalam menentukan maslah, merumuskan masalah, menentukan tahapan penyelesaian masalah, serta merencanakan percobaan untuk memeahkan masalah.

Keadaan ini menunjukkan bahwa kemampuan mahasiswa PGSD serta guru IPA SD masih perlu ditingkatkan. Apabila kondisi ini dibiarkan, dikhawatirkan akan mempengaruhi proses pembelajaran IPA di SD, karena banyak konsep-konsep dasar kimia yang terdapat pada konsep IPA di SD, seperti untuk tema udara ini. Upaya peningkatan literasi kimia mahasiswa PGSD dan guru SD sangat penting, mengingat literasi kimia berperan dalam meningkatkan literasi sains, Upaya peningkatan literasi kimia mahasiswa PGSD dan guru IPA SD perlu mendapat perhatian yang lebih serius, karena mereka yang akan mengaplikasikan konsepkonsep kimia pada siswa sekolah dasar. Ini sangat penting, mengingat betapa banyaknya aspek kimia dalam kehidupan sehari-hari yang juga terdapat dalam materi pembelajaran IPA di sekolah.

Peningkatan literasi kimia, terutama literasi kimia mahasiswa PGSD dapat dilakukan melalui perbaikan proses perkuliahan yang dilakukan, serta ruang lingkup materi konsep dasar kimia yang diberikan. Khusus untuk ruang lingkup materi konsep dasar kimia yang diberikan, penekanannya hendaknya bukan hanya pada konten (isi) dari ilmu kimia saja, melainkan terhadap konteks, proses, serta sikap. Hal ini sangat penting, karena penilaian literasi kimia menurut pisa bukan hanya pada konten saja, tetapi meliputi Context, Knowledge (knowledge of science and knowledge about science), serta attitudes (PISA, 2006). Salah satu upaya meningkatkan literasi kimia mahasiswa PGSD adalah melalui perbaikan proses pembelajaran yang dilakukan, yang tidak hanya menekankan pada penguasasan konsep, tetapi juga memperhatikan aspek lainnya. Salah satunya adalah melalui pebelajaran berbasais maslah (problem based lerning). Dalam pelaksanaannya, pembelajaran dapat dilakukan secara mandiri dan secara terbimbing. Untuk pembelajaran yang dilakukan secara mandiri, terutama pada hal-hal yang sederhana serta tidak asing bagi mereka. Sedangkan untuk pembelajaran terbimbing (dalam kelas) dilakukan untuk materi yang agak kompleks, yang memerlukan bimbingan, terutama dalam memecahkan masalah terkait dengan permasalahan dalam kehidupan seharihari pada tema udara.

\section{REFERENSI}

Arikunto, Suharsimi. (2013). Dasar-dasar Evaluasi Pendidikan. Jakarta: Bumi Aksara.

Brady and Holum. (1993). Chemistry The Study of Matter and Its Changes. Singapore: John Wiley \& Sons, Inc.

Gilbert, John K. and Treagust, David. (2009). Multiple Representations in Chemical Education. Australia: Springer.

Glenn V. Lo and Michael A. Janusa. (2010). Chemistry the Core Concepts. North Carolina: Kona Publishing and Media Group

Lin, Show-Yu. (2009). Chemical Literacy and Learning Sources of Non-Science Major Undergraduates on Understandings of Environmental Issues. Chemical Education Journal (CEJ), Vol. 13, No. 1.

Merwa, Eric and Zike, Dinah. (2005). Glencoe Science: Chemistry. Columbus, Ohio: The McGraw-Hill Companies, Inc. 
Mukhtar. (2013). Metode Penelitian Deskriptif Kualitatif. Jakarta: Referensi (Gaung Persada Press Group).

Paul Kelter, at all. (2009). Chemistry The Practical Science. Boston: Houghton Mifflin Company.

OECD-PISA. (2006). Science Competencies for Tommorow's Word. Volume 1: Analysis. USA: OECD-PISA. Tersedia www.pisa.oecd.org.

Sastrawijaya, Tresna. (2009). Pencemarn Lingkungan. Jakarta: Rineka Cipta.

Saud, Udin S. (2010). Pengembangan Profesi Guru. Bandung: Alfabeta.
Shwartz Yael; Ben-Zvi, Ruth, and Hofstein, Avi. (2005). The importance of involving highschool chemistry teachers in the process of defining the operational meaning Of 'Chemical Literacy' INT. J. SCI. EDUC, VOL. 27, NO. 3, 323-344.

Trefil, James and Hazen, Robert. (2010). Sciences an Integrated Approach. Sixth edition. Hoboken: John Wiley \& Sons. 